\title{
GRAVITY AND MAGNETIC INTEGRATED DATA INTERPRETATION OF THE CÓRREGO DOS BOIS COMPLEX, GOIÁS ALKALINE PROVINCE, CENTRAL BRAZIL
}

\author{
Yára Regina Marangoni ${ }^{1}$, Henglei Zhang ${ }^{1,2}$ and Herbert Jorge Ferreira ${ }^{1}$
}

\begin{abstract}
Previous studies carried out in some alkaline provinces around Paraná Basin, Brazil, show that most of the alkaline intrusions are related to high magnetic and gravity anomalies. In this study, both magnetic and gravity data are used to explore some of the alkaline intrusions of the Goiás Alkaline Province in Goiás State, near the northern Paraná Basin border. The total gradient and the normalized anisotropy variance methods were applied to detect the intrusions' locations; they show a strong correlation between outcrops and sources for the main bodies. Then, by combining the $3 \mathrm{D}$ inverted magnetization contrast from the magnetic data and the 2.5D forward model from both the gravity and magnetic data, it was possible to set a mass distribution model for the intrusion of Córrego dos Bois. The results show that this intrusion extends from the surface to almost $10 \mathrm{~km}$ in depth, with a density contrast of $0.4 \mathrm{~g} / \mathrm{cm}^{3}$ corresponding to a density value of $3.2 \mathrm{~g} / \mathrm{cm}^{3}$, which is coherent with those shown in the literature for the rocks in the area. Magnetic inversion resulted in anomalies that are very similar but circa $200 \mathrm{nT}$ lower than the observations at the positive lobe and no significant variation at the negative lobe. The magnetic source has $20 \mathrm{~A} / \mathrm{m}$ for magnetization.
\end{abstract}

Keywords: Brazilian alkaline, gravity anomaly, magnetic anomaly, inversion method, forward modeling.

RESUMO. Estudos anteriores em algumas províncias alcalinas ao redor da Bacia do Paraná, Brasil, indicaram que a maioria das intrusões alcalinas apresentam anomalias magnéticas de campo total de forte intensidade e anomalias Bouguer usualmente caracterizadas por altos gravimétricos. Neste estudo, dados de campos magnético e gravimétrico são utilizados para explorar algumas das intrusões alcalinas da Província Alcalina de Goiás, no Estado de Goiás, próximo à borda norte da Bacia do Paraná. Os métodos de gradiente total e variância normalizada da anisotropia foram aplicados para determinar a localização das intrusões, e mostraram boa correlação entre os afloramentos e as fontes de anomalia para os corpos principais. Combinando os resultados da inversão 3D do contraste de magnetização dos dados magnéticos com os modelos diretos 2,5D de dados gravimétricos e magnéticos foi possível estabelecer um modelo de distribuição de massa para a intrusão de Córrego dos Bois. 0 resultado mostra que essa intrusão se estende da superfície até cerca de $10 \mathrm{~km}$ em profundidade, com um contraste de densidade de 0,4 g/cm³, correspondendo a um valor de densidade de $3,2 \mathrm{~g} / \mathrm{cm}^{3}$, que é um valor de densidade coerente com os valores publicados na literatura para as rochas presentes na área. A inversão dos dados magnéticos da área de estudo resultou em anomalias muito semelhantes, com amplitudes positivas cerca de $200 \mathrm{nT}$ menores que a observada no lobo positivo, mas com pouca variação na amplitude das porções negativas das anomalias. A fonte magnética apresentou uma magnetização de 20 A/m.

Palavras-chave: alcalinas brasileiras, anomalia gravimétrica, anomalia magnética, método inverso, modelagem direta.

\footnotetext{
1 Universidade de São Paulo, Instituto de Astronomia, Geofísica e Ciências Atmostéricas, Departamento de Geofísica, Rua do Matão, 1.226, Cidade Universitária, 05508-090 São Paulo, SP, Brazil. Phone: +55(11) 3091-4741; Fax: +55(11) 3091-5034 - E-mails: yaramaran@usp.br; herbert.ferreira@iag.usp.br ${ }^{2}$ China University of Geosciences, Institute of Geophysics and Geomatics, 388 Lumo Road, Wuhan, P.R. China, Postal Code: 430074, Phone: +86(27) 8748-1030; Fax: +86(27) 8748-1030 - E-mail: sky0610@163.com
} 


\section{INTRODUCTION}

The Brazilian territory in the South American plate is marked by alkaline intrusions (Ulbrich \& Gomes, 1981; Gomes et al., 1990), and the borders of Paraná Basin in the south part of the continent has at least five different provinces of alkaline intrusions (Riccomini et al., 2005 and references therein). Marangoni \& Mantovani (2013) presented a review of the gravity and magnetic signals for three provinces around the Paraná Basin: the Goiás Alkaline Province (GAP) and Alto Paranaíba Province, both at the northeastern border, and the Ponta Grossa Arch Alkaline Province at the southeastern border. These three provinces are composed of groups of 5 to 10 intrusions. Most of the known intrusions have a common feature of marked gravity and magnetic anomalies. The Bouguer anomalies usually display gravimetric highs related to denser mafic and ultramafic rocks. The magnetic anomalies are bipolar with strong intensity for the negative and positive lobes. The mafic rocks usually contain large amounts of magnetic minerals which produce the observed magnetic anomalies. The alkaline complexes present induction magnetization, from the interaction with the present day magnetic field, and remanent magnetization, which relates with the age and geological history of the intrusions (Drenth et al., 2015). A few intrusions present reverse magnetization direction at the Alto Paranaíba Province and the Ponta Grossa Arch Alkaline Province, but not at GAP.

Marangoni \& Mantovani (2013) have pointed out that the gravimetric and magnetic fields from the intrusions in the provinces mentioned earlier show a strong relationship with outcrops. The presence of similar large amplitude gravity and magnetic highs anomalies in areas covered by sediments inside or near the provinces around Paraná Basin have led the researchers to propose that those anomalies are caused by some concealed intrusions by analogy with observations related to mafic ultramafic outcrops. Drenth et al. (2015) also interpreted large amplitude gravity and magnetic highs as intrusive complexes of mafic ultramafic rocks that intruded the crystalline basement and are covered by Paleozoic sediments along the lowa-Minnesota border (USA). Drenth et al. (2015) made the analogy comparing results from geophysical data with known outcrops near their study area.

Dutra \& Marangoni (2009) studied the gravity and aeromagnetic anomalies from Morro do Engenho (ME) and "A2 magnetic anomaly" (A2MA), as named by CPRM - Brazilian Geological Survey - in the Interpretative Magnetic Anomaly Map of the Goiás Alkaline Province (Prospec, 1974). ME has a Bouguer anomaly of $+15 \mathrm{mGal}(+45 \mathrm{mGal}$ after the removal of a regional field) and a magnetic anomaly (total field with IGRF removed) of $-2500 \mathrm{nT}$ to $+1000 \mathrm{nT}$ (negative and positive lobes, normal magnetization) over the intrusion outcrop. A2MA also shows a high amplitude Bouguer anomaly of $-4 \mathrm{mGal}(+22 \mathrm{mGal}$ of residual anomaly) and magnetic anomaly stronger than ME, varying from $-4000 \mathrm{nT}$ to $+3000 \mathrm{nT}$. But at the anomaly site the authors could not find any outcrop, just sediments from the Araguaia River. Dutra \& Marangoni (2009) modeled the A2MA as a concealed mafic ultramafic alkaline intrusion (Fig. 7 in Dutra \& Marangoni, 2009) using ME geophysical response as a model.

Mantovani et al. (2005) made a geophysical survey integrating gravity, magnetic and shallow seismic refraction signals over a small magnetic anomaly, mapped in the aeromagnetic survey of the Ponta Grossa Arch Alkaline Province. They obtained a Bouguer gravity anomaly similar to others gravity anomalies correlated to mapped intrusions in the province. The seismic refraction inferred an igneous intrusion with top at $40 \mathrm{~m}$ of depth, covered by sediments. Again the potential fields anomalies (gravity and magnetic) were interpreted as responses from a concealed source, possibly a magmatic intrusion.

More examples of interpretation of integrated gravity and magnetic data over alkaline complexes around the world can be find in the literature. Chandrasekar et al. (2002) studied some anomalies over Deccan volcanism in Saurashtra, India, they used 2.5D forward model in profiles since data distribution was not enough to use 3D modeling. They found some gravity and magnetic highs that were interpreted as volcanic plugs in areas where the intrusions were only partially exposed. Arzamastsev et al. (2000) modeled the Kola Alkaline Province intrusion by 3D inversion of density. The Kola Alkaline Province has a few intrusions with high amplitude Bouguer anomalies, almost circular shape, located very close to each other, some are zoned intrusions with different materials from inside core to the rim, like the GAP. 3D density distribution obtained spherical mass distribution usually with denser material at the center. Like the results from GAP (Dutra et al., 2012) the density distribution form Kola are limited to the upper crust. Dindi \& Swain (1988) modeled the Jombo Hill alkaline complex, Kenya, by a 3D inversion of gravity and magnetic data. They got denser material close to the surface, where the ultrabasic rocks crops out, less denser material extended through the upper crust, but the authors pointed out that probably the complexes cut all the crust.

This paper presents the results from a gravity survey and integration with aeromagnetic data for some known intrusions at the north part of the Goiás Alkaline Province (GAP): Córrego dos Bois Complex and Fazenda Buriti Complex. The main objective is to set the mass and magnetic material distribution at subsurface. 


\section{GEOLOGICAL BACKGROUND AND PREVIOUS WORK}

The GAP is located at the northern border of the Paraná Basin. Junqueira-Brod et al. (2002) divided it into three sections with respect to the magmatic products. The north section is characterized by plutons of mafic-ultramafic alkaline rocks. It comprises the intrusions of Morro do Engenho (\#1, in Fig. 1), Santa Fé (\#2), Montes Claros (\#3), Arenópolis (\#8), Iporá, with three intrusion: Córrego dos Bois (\#5), Morro dos Macacos (\#6), Fazenda Buriti (\#7), and Diorama (\#4). In the central section it is possible to find small plutons, like Amorinópolis (\#9), and diatremes, like Águas Emendadas (\#10). The south section is characterized by the large kamafugite lava flow of Santo Antônio da Barra (\#11) (Junqueira-Brod et al., 2005). Figure 1 presents a simplified geological map of the region in which the alkaline intrusions are numbered. It includes two inferred intrusion by geophysical methods that are buried under the sediments of Araguaia River, Registro Araguaia (\#12) and A2 Magnetic Anomaly (\#13). The studied anomalies are in the marked area of Figure 1 , in the south limit of the north section.

The intrusions are emplaced into the orthogneiss and syntardi granites (calcialkaline granite, granodiorite, quartz diorite and quartz monzodiorite), and post-tectonic granites (alkalifeldspar granite, hornblende-biotite porphyry monzogranite, syenogranite, quartz monzodiorite granodiorite quartzodiorite) related to the Goiás Magmatic Arc (Lacerda Filho, 2000). They also intrude in the Paleozoic sediments of the Paraná Basin (Furnas and Ponta Grossa Formations of Paraná Group), and quaternary sediments of Araguaia Formation. Sediments of Araguaia Fm. are unconsolidated silt argillaceous to sandy. Furnas Fm. is composed of feldspathic sandstone, micaceous and basal conglomerate (Lacerda Filho, 2000). Ponta Grossa Fm. is composed of fine sandstone, feldspathic, micaceous; basal conglomerate; and interbedded shales, silty shale, siltstone, conglomerate and ferruginous sandstone (Lacerda Filho, 2000).

In the region studied in this paper crops out the intrusions of Diorama region (\#4) (Fig. 1), Córrego dos Bois Complex (\#5), Morro do Macaco Complex (\#6) and Fazenda Buriti Complex (\#7). Diorama region is characterized by subvolcanic intrusion, dikes, plugs, and sills of picrite. Sills and dykes extend for dozens of meters, whereas plugs are a few hundred meters in diameter. Córrego dos Bois Complex covers an area of approximately $33 \mathrm{~km}^{2}$ and Morro do Macaco Complex is a zoned intrusion of dunite, wehrlite, olivine pyroxenite, and clinopyroxenite from core to rim. The Fazenda Buriti Complex has $35 \mathrm{~km}^{2}$ of area with olivine clinopyroxenite, melagabbro, syenogabbro, and syenite as main lithologies. A detailed discussion on the geology of the intrusions is found in Junqueira-Brod et al. (2002). The rocks of these intrusions are denser and with more magnetic mineral than the rocks from the Goiás Magmatic Arc and Paleozoic sediments. It is expected large amplitude magnetic and gravity anomalies.

The geophysical signature of part of the north section of the GAP has already been studied (Dutra \& Marangoni, 2009; Dutra et al., 2012), while the central and south sections are still in the need of geophysical modeling. The north section displays large postive Bouguer anomalies with amplitudes varying from +20 to $+70 \mathrm{mGal}$. The magnetic anomalies show all normal direction of magnetization, with maximum and minimum amplitudes varying from $+6000 \mathrm{nT}$ to $-5000 \mathrm{nT}$. The models for anomalies in the north section of the GAP resulted in subsurface distribution of mass and magnetic material whose geometrical shape resembles spheres or short cylinders (Dutra \& Marangoni, 2009; Dutra et al., 2012). The spatial distribution of mass has been interpreted as magma chambers, some of them crop out and some are covered by Quaternary sediments of Araguaia River.

\section{GEOPHYSICAL DATA}

\section{Aeromagnetic data}

Between 2004 and 2006 Brazilian Geological Survey and Goiás State government provided an intense aeromagnetic survey of high quality. In this paper it was used the aeromagnetic data acquired from June to November of 2004, at the SW of Goiás State. The survey was performed along north-south oriented acquisition lines with $500 \mathrm{~m}$ spacing and east-west oriented control lines with $5 \mathrm{~km}$ spacing. The flight height was $100 \mathrm{~m}$. Observations were taken at a rate of 10 measurements per second and were positioned by GPS with accuracy of $\pm 10 \mathrm{~m}$. More details on the processing of the raw data and survey parameters can be found in the survey report (LASA, 2004). The magnetic anomaly map (Fig. 2) was obtained after the removal of the International Geomagnetic Reference Field (IGRF) from the aeromagnetic survey. In Figure 2 it is possible to see that the magnetic anomaly field is more positive than expected for the magnetic latitude. This happens because there are few geomagnetic observatories in South America compromising the resolution of IGRF in the area. Hence, a polynomial tendency with a second order was removed in the study area (Fig. 3a).

The total gradient has been used as a tool to detect the edges of the magnetic anomaly source (Fig. 3b). The total gradient is obtained from the horizontal $(x, y)$ and vertical $(z)$ derivatives of the magnetic field; it presents the maximum value over the magnetic contrast (Roest et al., 1992). The total gradient does 


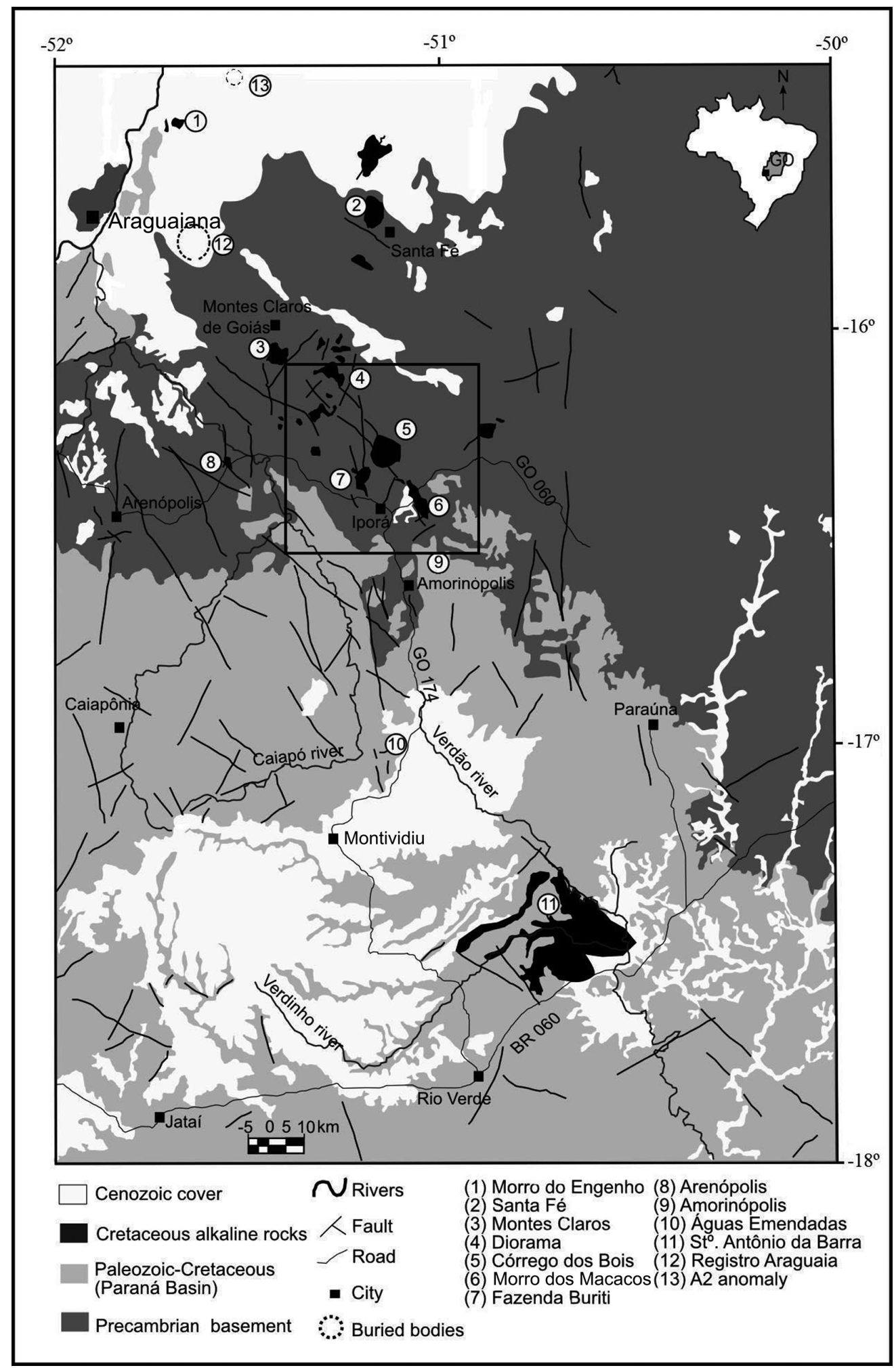

Figure 1 - Simplified geological map of the Goiás Alkaline Province adapted from Junqueira-Brod et al. (2005) and Dutra et al. (2012). Inset shows the GAP location. Square marks the study area and numbers refer to the alkaline intrusions. 


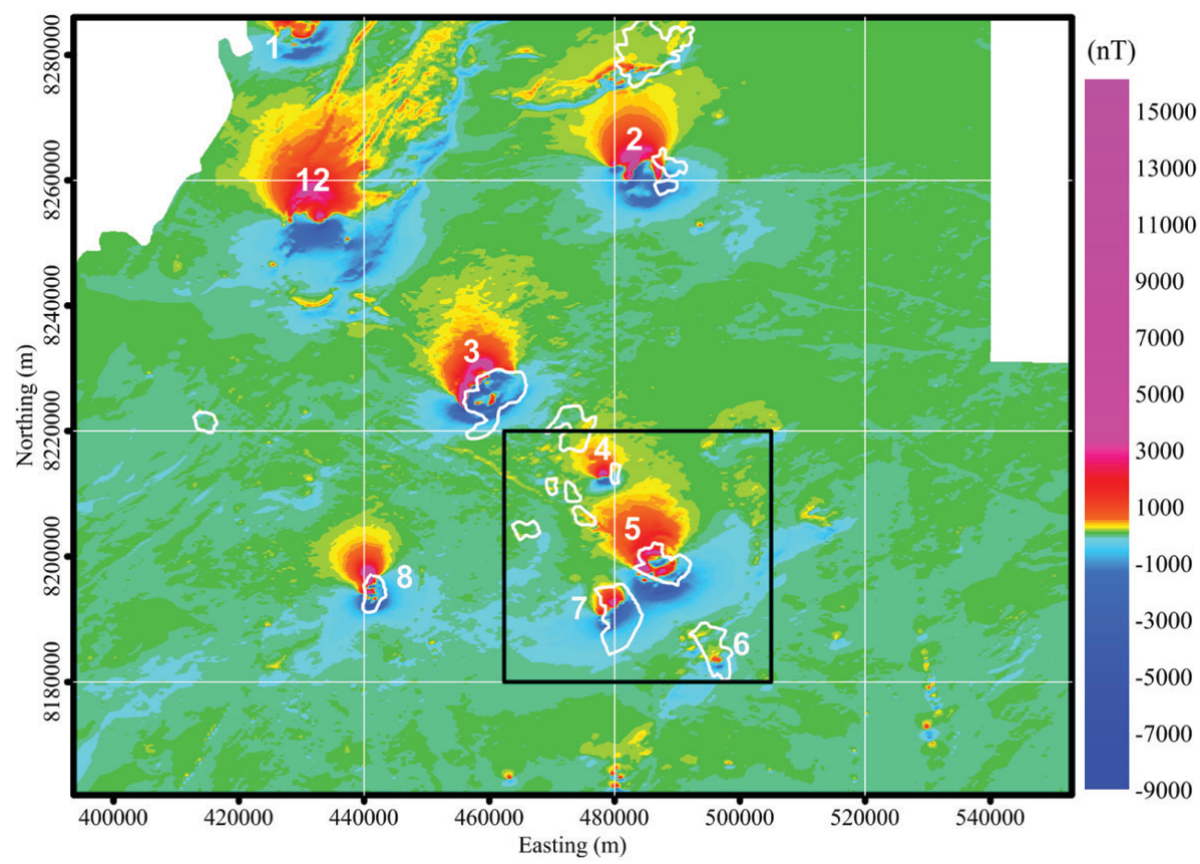

Figure 2 - The magnetic anomaly map of north section of the GAP. The white lines show the boundaries of the alkaline intrusion outcrops obtained by geological map (Lacerda Filho, 2000). The grid interval used for generating the anomaly map was $125 \mathrm{~m}$ by $125 \mathrm{~m}$. The black square marks the anomalies studied in this work.

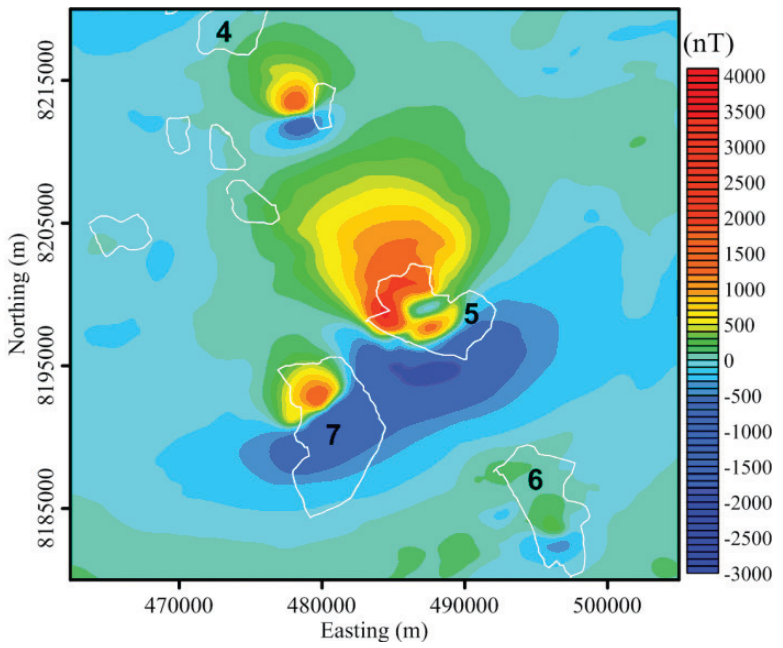

(a)

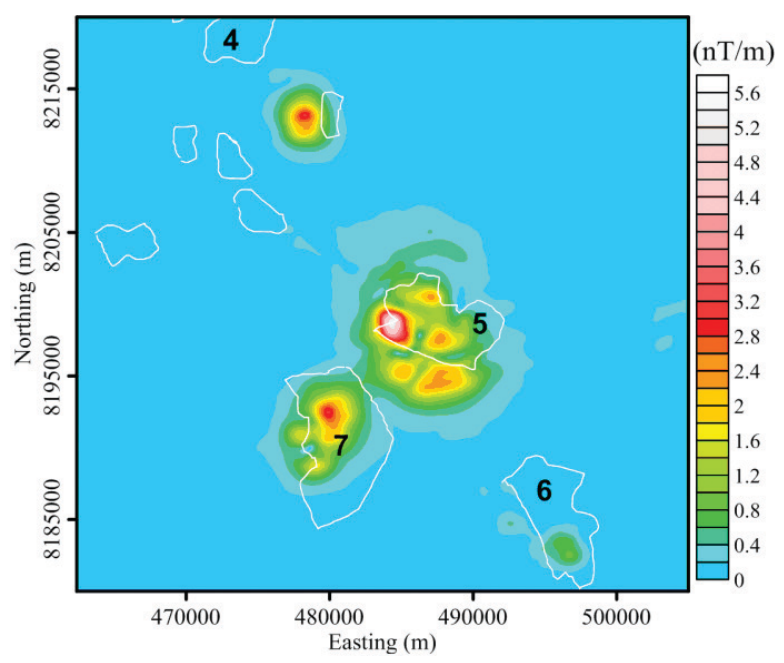

(b)

Figure 3 - The magnetic anomaly map (a) of the black square in Figure 2 after removal of polynomial surface and its total gradient (b).

not depend on the magnetization direction for a $2 \mathrm{D}$ case, and it reduces the effect of magnetic field direction for a 3D case.

\section{Gravity Data}

Ground gravity data was collected at 817 stations in the area over a span of time of three decades, using a LaCoste-Romberg, type $G$ gravimeter of $0.01 \mathrm{mGal}$ accuracy. Coordinates were acquired by topographic maps and GPS. Elevations were acquired from bench marks, barometric altimeters for the earlier gravity acquisition, and high precision GPS for the new gravity data. All stations were adjusted to the WGS84 coordinate system and terrain correction was applied. The values were corrected using the normal gravity 
formula of 1967 and the density for the Bouguer correction was set as $2.67 \mathrm{~g} / \mathrm{cm}^{3}$. Gravity data has an average accuracy of $1 \mathrm{mGal}$, considering the different methodologies to get the $(x, y, h)$ coordinates. The Bouguer anomaly for the whole area of the GAP is in Figure 4.

In the study area (marked by the black square in Fig. 4) the intrusions are close and it is difficult to separate the gravity effect of each source (Fig. 5a) because of the superposition principle. In order to remove this effect and enhance anomalies the NAV-edge method (Zhang et al., 2014b) was applied to the data (Fig. 5b). The NAV-edge method (Zhang et al., 2014b) detects the source edges for potential fields based on the idea of normalized standard deviation with the application of an anisotropic Gaussian function designed to detect the directional edges. It was designed to avoid the use of high-order derivatives directly in the calculation and so, to reduce the sensitivity to noise.

\section{GEOPHYSICAL MODELING METHODOLOGY}

The aeromagnetic data (Fig. 2) is dominated by the effect of crystalline basement, and the effect of the alkaline intrusions outcrops. Some small anomalies are scattered mainly in the south of the area. The background (green color in Fig. 2) is marked by a tendency NW-SE, and SW-NE at the southwestern part of the map, a region covered by Paleozoic sediments of Paraná Basin. We supposed that these tendencies represent crystalline lineaments. The gravity is marked by the effect of the Paleozoic sediments in the south part of the area (not covered by the aeromagnetic data of Fig. 2) where the Bouguer anomaly has the lowest values in the area. In the north part the anomalies have higher amplitude and possible reflect the effect of the intrusions and the denser lithology of the Goiás Magmatic Arc compared to the sediments. Based on these observations we made some assumptions to set limits for petrophysical properties during modeling and interpretations. We assume that high amplitude Bouguer and magnetic anomalies reflect a mafic ultramafic composition for the source. Strongly magnetized anomalies but with no correspondence in Bouguer anomaly are supposed to be derived from more silicic rocks (Drenth et al., 2015) or mafic rocks with a poor gravity coverage.

In this paper we applied the total gradient and NAV-edge methods on analyzing the magnetic data and the ground gravity data to enhance the anomalies. Models for the anomalies sources were based on inverse and forward modeling.

The 3D inversion methodology applied in the magnetic data (Figs. 6 and 7) is based on probability method developed and first introduced for analyzing self-potential field data (Patella, 1997a,b). Later, it was applied to electromagnetic data, gravity data, and magnetic anomaly (Mauriello \& Patella, 1999, 2001ab, 2008; Iuliano et al., 2002). The method was modified by Zhang et al. (2014a) discussed in an internal report and presented in the Appendix A.

In order to compare results in-depth, a 2.5D forward model with optimization (Fig. 8) was performed. The alkaline intrusions are clearly best described by 3D structures. In potential field interpretations it is not unusual to suppose that a 3D geological body may be simplified as a 2.5D structure, see for instance Drenth et al. (2015); Boot \& Tantrigoda (1987); Chandrasekhar et al. (2002). This is frequently used to model gravity and magnetic data at the same time and when one of the data set is not so large. Both situations applied in this work. The 2.5D forward model, based on Okabe (1979), was applied at a NS profile marked on Figure 6.

\section{GEOPHYSICAL RESULTS AND DISCUSSION}

\section{Aeromagnetic and gravity results}

Figure 2 shows the magnetic anomaly map of the north and central sections of the GAP. There is a strong correlation between the outcrops (white lines in Fig. 2) and magnetic anomalies in most part of the area covered by the aeromagnetic survey. The amplitude of the magnetic anomaly in the studied area (marked by the black square in Fig. 2) varies from -9000 to +16000 nT. A few small outcrops, located west of anomalies \#4 and \#6, have no magnetic anomaly association. The anomalies in the area show normal polarity but the magnetic intensity and direction are incompatible with the present magnetic field. This indicates that a remanent magnetization might be acquired during the intrusions emplacement. The emplacement may have occurred during a geological time of a normal magnetic field but with different intensity from the present one. The remanent magnetization was confirmed by Dutra et al. (2014) by magnetic measurements on a few oriented samples from intrusions in the north section.

After the second order polynomial tendency was removed in the study area (Fig. 3a) the new magnetic anomaly field is more symmetrical than that on the map of Figure 2. The total gradient routine was applied to the data after the removal and the results are shown in Figure 3b. When the remanence is strong and the total magnetization field has a different direction than the induced field, the use of total gradient can help in determining the locations of the magnetic sources. Anomaly \#5 exhibits more than one maximum as a result of the total gradient technique and can be interpreted as an agglomerate of bodies, whereas anomalies \#4, \#6 and \#7 seem to be due to individual intrusions because they appear to be near the maximum displayed locally. 

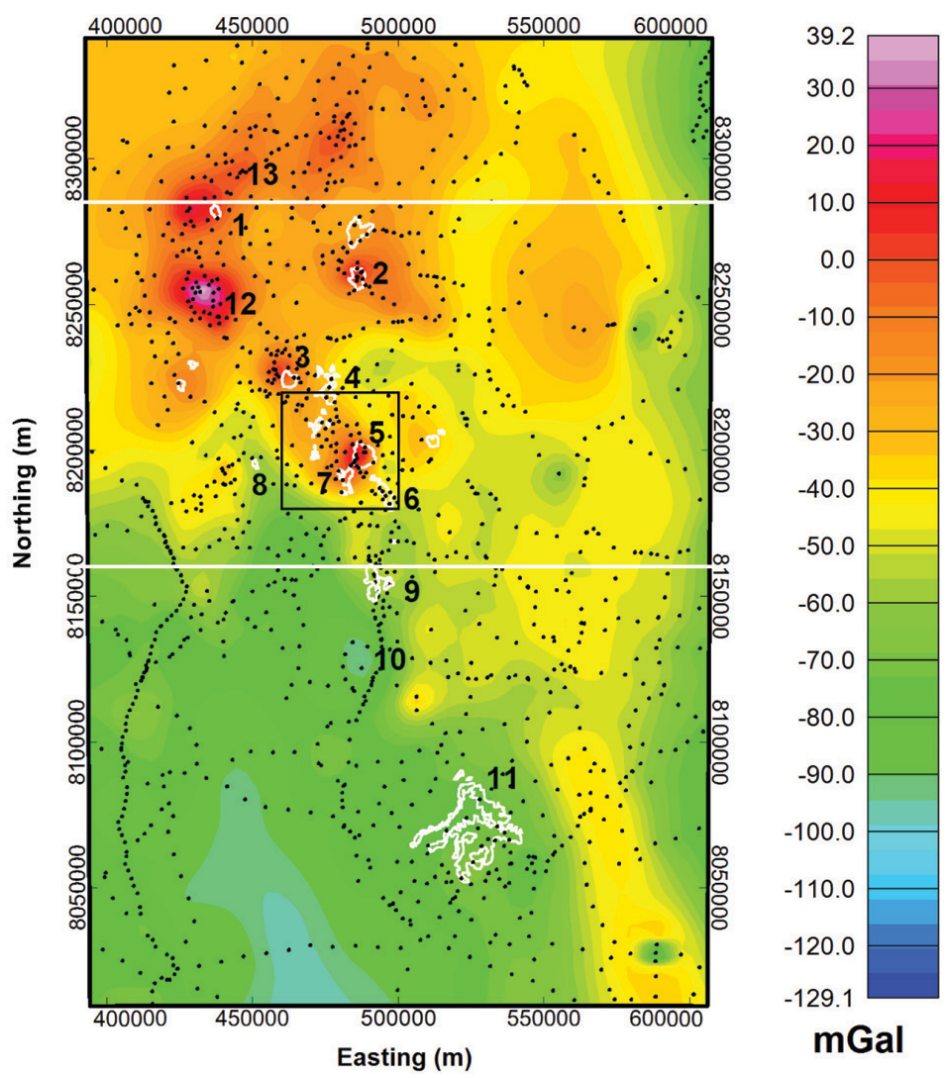

Figure 4 - The Bouguer anomaly map of the GAP. The white solid lines show the boundaries of the alkaline intrusion outcrops obtained by detailed geological map (Lacerda Filho, 2000). The black square marks the anomalies studied here. The grid interval for the contour map is $1 \mathrm{~km}$ by $1 \mathrm{~km}$. The white EW lines delimit the magnetic observation area shown in Figure 2. The black dots mark gravity stations.

The Bouguer anomaly for the whole area of the GAP is in Figure 4. The Bouguer anomalies display high values over the NW section of the map. Some high, large amplitude anomalies correlate with outcrops. In the central part of the area, over the $\mathrm{Pa}$ leozoic sediments, the lateral density contrast makes the anomalies sharper. The mafic ultramafic plutons of north section show Bouguer anomalies with high positive amplitudes. The central and south part of the GAP are represented by the intrusion of Amorinópolis (\#9) and the lava flow of Águas Emendadas (\#10), both with subvolcanic character, and the kamafugitic lava flow of the Santo Antônio da Barra (\#11). Amorinópolis and Santo Antônio da Barra have no visible gravimetric anomaly. Águas Emendadas display a negative anomaly of approximately $-8 \mathrm{mGal}$. Neither of them has been recovered by the aeromagnetic survey used here.

Figure 5 shows the Bouguer anomaly map of the study area. In this map, it is difficult to separate the gravimetric signal apparently derived from anomalies \#5 and \#7. The data distribution in the area is not ideal, there are not much available stations, besides the size of the outcrops and the proximity of them would make the anomalies separation difficult even if there are much more data. To enhance the anomalies the NAV-edge method (Zhang et al., 2014b) was applied to the data. The results are shown in the Figure $5 b$, in which the zero value shows the detected edges and the warm colored areas show the source locations. The application of the NAV-technique allowed better differentiation between the anomaly \#5 and anomaly \#7. Although there are not as many anomalies as determined by the total gradient (Fig. 3b), the NAVedge individualized the intrusions \#5 and \#7. Small outcrops in the west are detected by the NAV-edge map show in Figure $5 b$. They have not been marked by the Bouguer anomaly (Fig. 5a) and magnetic anomaly (Fig. 3a).

\section{Results from 3-D Inversion of Magnetic Data by Probability Method}

The results of the application of the inversion scheme (proposed here, Appendix A) to the magnetic data from anomaly \#5 are shown in Figures 6 and 7 . The inversion was performed with the data from the magnetic field after upward continuation to $850 \mathrm{~m}$ 


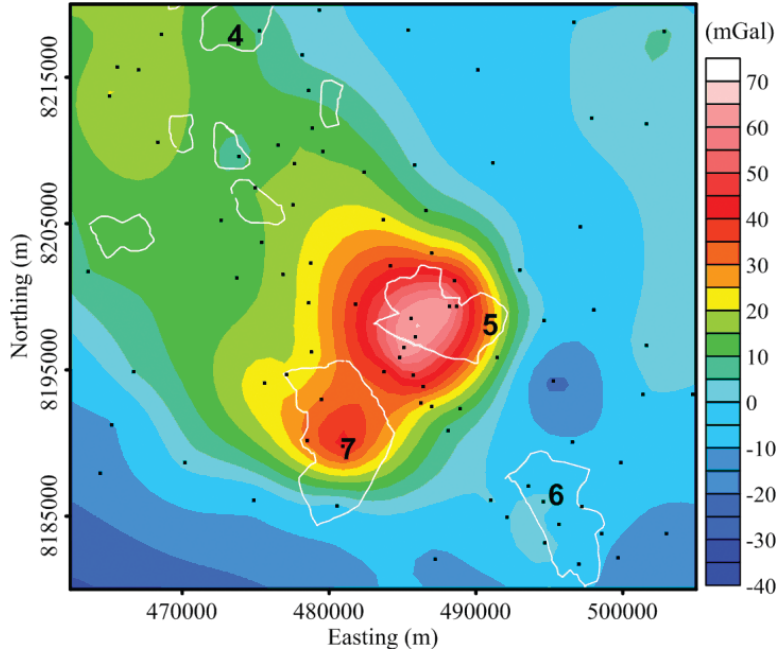

(a)

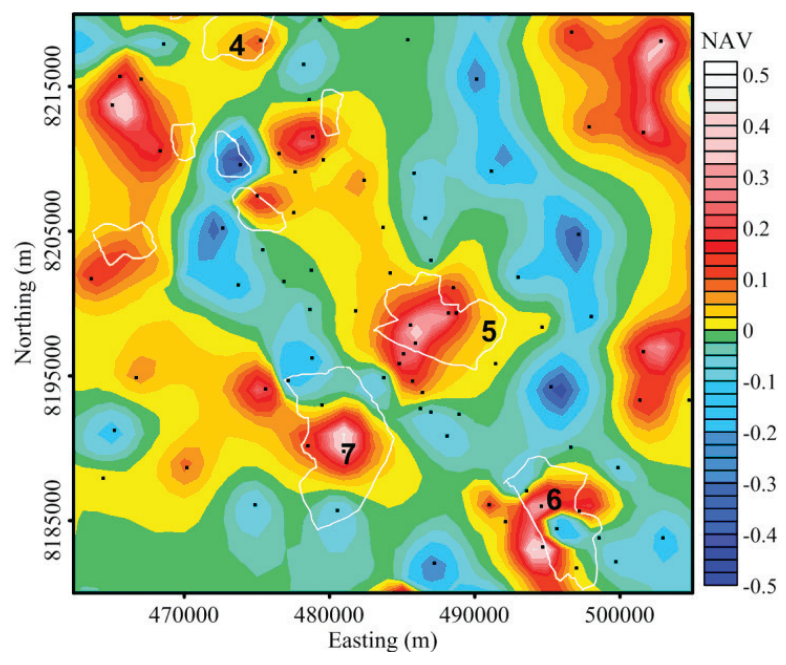

(b)

Figure 5 - The local Bouguer anomaly map (a) of the black square in Figure 4 and its source edge detection (b).

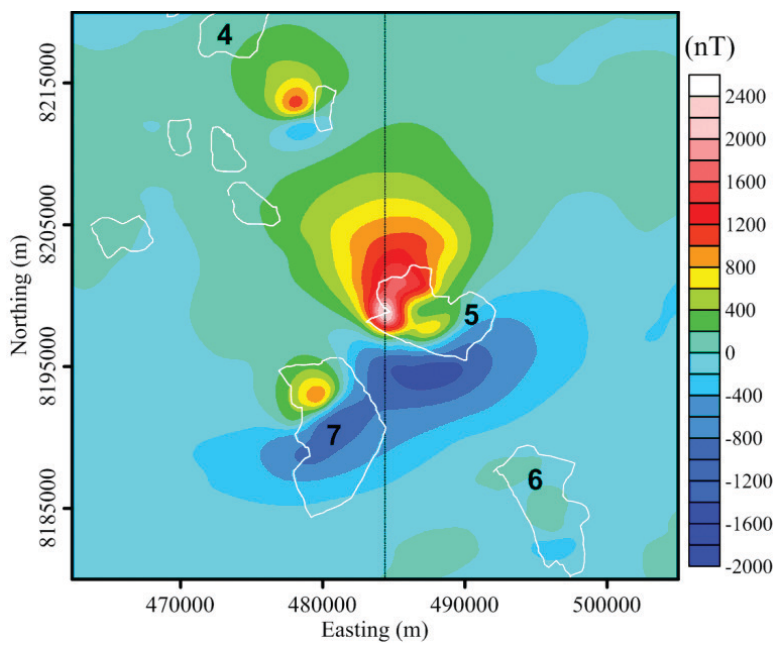

(a)

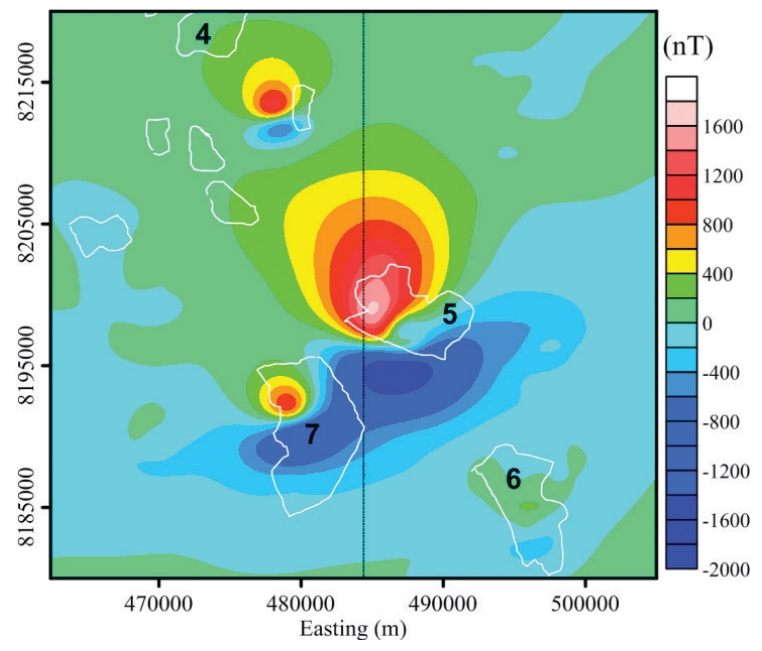

(b)

Figure 6 - (a) Magnetic anomaly used for the 3-D inversion approach (this anomaly is upward continued with $850 \mathrm{~m}$ corresponding to Fig. 3b); (b) the modeled anomaly based on the 3-D inversion.

to reduce noise effects. As expected, the modeled anomaly in the inversion process (Fig. 6b) reproduces quite well the observed anomaly (Fig. 6a). The distribution of magnetization in-depth resulted from 3-D inversion (Fig. 7) defined anomaly \#5 as the result from a intrusion that may be represented by one block with magnetization distributed along an almost spherical shape located inside the upper crust. The result can be interpreted as a possible magma chamber and is similar to the one obtained from the NAV-edge (Fig. 5b) for gravity anomaly with one source for the gravimetric signal. A deep source, in the middle of the crust, appears northeast of anomaly \#5 (central part of Fig. 7) and has no corresponding gravity and magnetic signal. We suggest that it is the response from some structure inside the Precambrian rocks in the area.

\section{Gravity and magnetic forward modeling}

The results of a 2.5D forward model with optimization are shown in Figure 8 separately for gravity and magnetic signal to facilitate the visualization.

Results from gravity and magnetic signals show similar features to the 3D inversed model shown in Figure 7. The distribution of density in-depth shows that the intrusion of Córrego dos Bois 


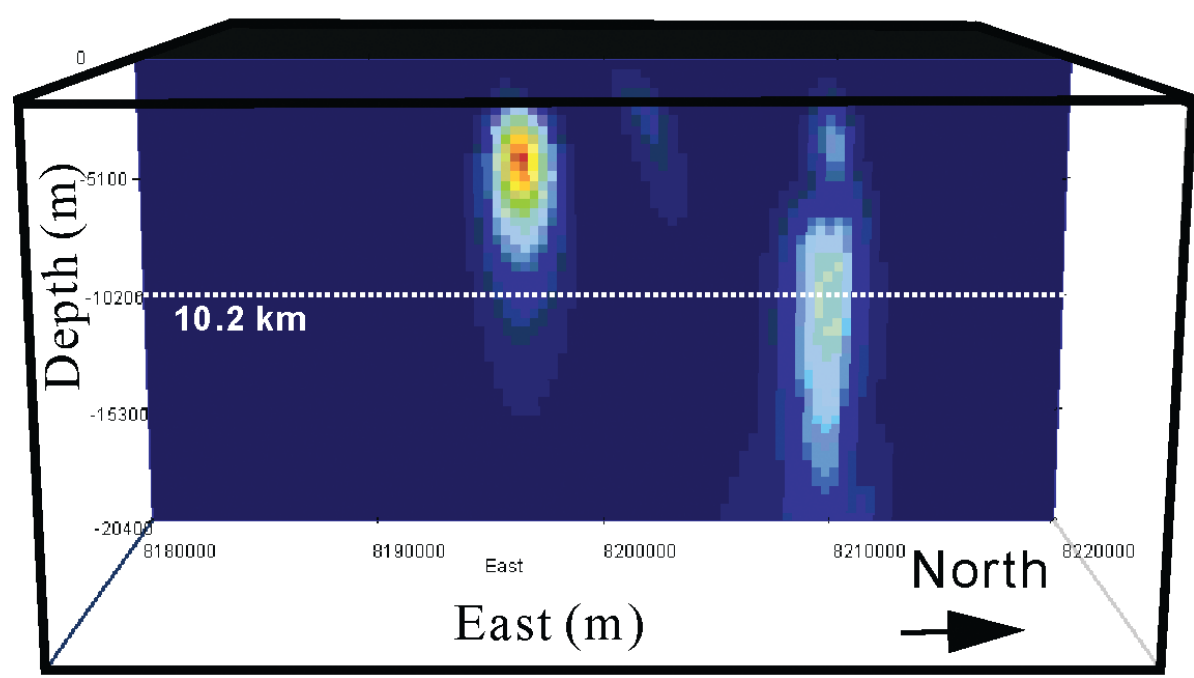

Figure 7 - Magnetization distribution in-depth for anomaly \#5. This section shows the magnetization distribution along the profile shown in Figure 6 from South to North.

(anomaly \#5) extends from the surface to almost $10 \mathrm{~km}$ in-depth, with a density contrast of $0.4 \mathrm{~g} / \mathrm{cm}^{3}$ that corresponds to a density value of $3.07 \mathrm{~g} / \mathrm{cm}^{3}$; this value is consistent with the density values in the literature for the same rocks in the area (Dutra et al., 2012; Ahrens \& Johnson, 1995). Results from the 2.5D magnetic modeling (Fig. 8) shows similar features to the 3D inverted model show in Figure 7. Both of them shows the high magnetization located at $\sim 8197000 \mathrm{~m}$, centered at a depth of $5 \mathrm{~km}$, and size of $9 \mathrm{~km}(3 \mathrm{D})$ and $1.6 \mathrm{~km}(2.5 \mathrm{D})$ for width. The difference in width is a consequence of using $3 \mathrm{D}$ or $2.5 \mathrm{D}$ dimension for modeling. As in other forward modeling results (Dutra \& Marangoni, 2009), the magnetization distribution looks much more focused along the central axis of the intrusion, and this is in accordance with the geological characteristic of the intrusions from the GAP. Most of them present a core with more magnetic and dense rocks that are ringed by less magnetic rocks. The size of the anomaly and its burial depth is consistent with those from other intrusions in the GAP (Dutra \& Marangoni, 2009; Dutra et al., 2012) and other provinces around Paraná Basin (Marangoni \& Mantovani, 2013).

\section{CONCLUSIONS}

The maps of Figures 2 and 4 confirms the strong relationship between the magnetic and gravity anomalies, even considering that the spatial density of the gravity data is much lower than the aeromagnetic data in the same area. The relationship can be related with the mafic-ultramafic lithology of the mapped intrusions. The intrusions are characterized by high density rocks with high content of magnetic minerals. Dutra \& Marangoni (2009) have analyzed some samples collected at outcrops in the north section and they resulted in weathered material with reduced density, compared with density values in the literature for the rock types, but, analyzing thin sections of rocks in microscope, they found that the magnetite was preserved. This explains why anomalies \#4 and \#6, have small amplitude Bouguer anomaly (Fig. 4) but shows intense magnetic anomaly (Fig. 3).

The Bouguer anomaly map from all the GAP, showed here for the first time (Fig. 4), shows the differences in the gravimetric signal of the regions of the province. In the north section, the anomalies are large in size and amplitude, most of them are located over outcrop intrusions. In the central section and in limited areas within the north section close the Paraná Basin the anomalies are smaller, and it is not always easy to find any correspondence with scattered, small outcrops in the area. The south part of the province, Santo Antônio da Barra, show a negative Bouguer anomaly. We interpreted that as the signal of the basin sediments instead of the kamafugitic lava flow. As discussed by Junqueira-Brod et al. (2005) the lava flows are centimeters thick and a few hundred meter long, interlayered with and overlain by sediments of Paraná basin.

The aeromagnetic survey does not cover the south section of the GAP, since the survey's goal is to cover the Precambrian terrains and the south section is inside the Paraná Basin, just at the border. The data from the central section shows strong magnetic anomalies related to Córrego dos Bois (anomaly \#5) and Fazenda Buriti (anomaly \#7) intrusion and a small magnetic anomaly for 

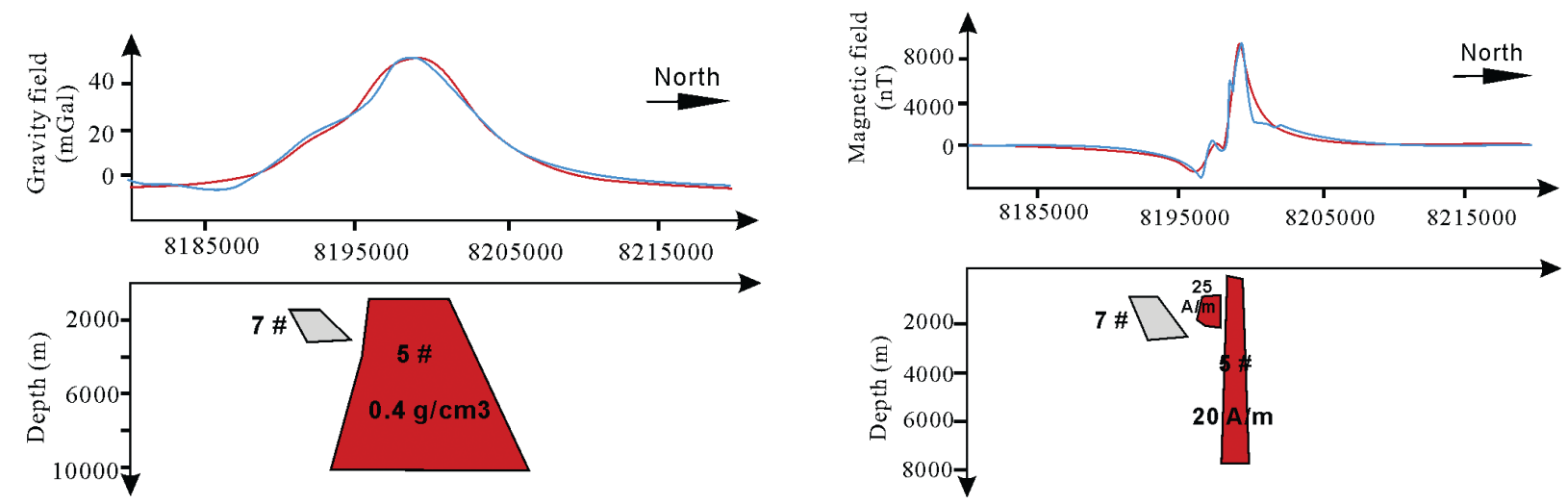

Figure 8 - Forward model for gravity and magnetic data along a profile south-north through anomaly \#5. The blue lines show the observed fields and the red lines show the modeled fields.

Morro dos Macacos (anomaly \#6) intrusion (Fig. 2). The use of the total gradient (Fig. 3) shows the source position for the anomalies in the region and clearly separated sources for anomalies \#5 and \#7.

The inversion of magnetic data and forward model for gravity and magnetic data along a south-north profile crossing anomaly \#5 indicates that the source is inside the upper crust, with depth of no deeper than $10 \mathrm{~km}$. Its size has some resemblance to a magmatic chamber and, as predicted by models for the north section, denser rocks occupy a volume larger than the magnetic material. The magnetic source is located almost in the center of the denser block with $1.6 \mathrm{~km}$ thick, magnetization of $20 \mathrm{~A} / \mathrm{m}$, and a small body, south of the main one, with a magnetization of $25 \mathrm{~A} / \mathrm{m}$. Gravity modeled just one source, almost $8 \mathrm{~km}$ in the SN direction and density contrast of $0.4 \mathrm{~g} / \mathrm{cm}^{3}$, that results in density of $3.07 \mathrm{~g} / \mathrm{cm}^{3}$, compatible with mafic rocks. Values for density contrast and magnetization are in agreement with results reported in the literature. The results from the models in this paper are limited by the small amount of gravity data, but it is complemented with aeromagnetic data.

\section{ACKNOWLEDGEMENTS}

This work was financially supported by the Fundação de Amparo à Pesquisa do Estado de São Paulo (FAPESP - Research Foundation of São Paulo State) (2012/00593-9 and 2012/06082-6). Aeromagnetic data was provided by Serviço Geológico do Brasil (CPRM - Brazilian Geological Survey) and Superintendência de Geologia e Mineração/Secretaria de Indústria e Comércio do Estado de Goiás. We are very thankful to the reviewers.

\section{APPENDIX A: 3D INVERSION OF MAGNETIC DATA}

The probability method for magnetic anomaly is defined as follows:

$$
\left\{\begin{array}{c}
p(i)=C_{i} \int_{-X}^{X} \int_{-Y}^{Y} f^{o b s}(r) s\left(r_{i}-r\right) g(z) d x d y \\
C_{i}=\sqrt{\begin{array}{l}
\int_{-X}^{X} \int_{-Y}^{Y}\left[f^{o b s}(r)\right]^{2} g(z) d x d y \\
\times \int_{-X}^{X} \int_{-Y}^{Y} s^{2}\left(r_{i}-r\right) g(z) d x d y
\end{array}}
\end{array}\right.
$$

where $(-X, X)$ and $(-Y, Y)$ are the locations along $x^{-}$, and $y$-direction; $r$ is the observed station, and $r_{i}$ is the location of the $i$ th element; $f^{o b s}$ is the observed magnetic data, $s$ is the scanner function, $g(z)$ is a topography regularization factor and expressed by:

$$
g(z)=\sqrt{1+(\partial z / \partial x)^{2}+(\partial z / \partial y)^{2}} .
$$

In equation (A1), the function $s\left(r_{i}-r\right)$ is called the spacedomain scanner function. Iuliano et al. (2002) suggest using an elementary positive source of unit strength to make the scanner function, and then it is applied to scan the whole space to search where the actual sources are most probably located. Since the probability function in Equation (A1) is normalized by $C_{i}$, the probability value $p$ ranges from -1 to +1 .

Fedi \& Pilkington (2012) point out that the probability method can not provide an estimate of the density values. To counterpoint the questions posed by luliano et al. (2002), it has been studied by using a 3D inversion method for potential field data based on the idea of the probability method with inverting the magnetization and/or density efficiently. Where the idea is applying an iteration function of the form:

$$
M_{j+1}=M_{j}+\Delta M_{j+1}\left(f_{j}^{r e s}\right)
$$


where $M_{j+1}$ and $M_{j}$ are the estimated magnetizations or densities after $j+1$ and $j$ iterations, respectively; $\Delta M_{j+1}$ denotes the model increase after $j+1$ iterations. The residual anomaly is:

$$
f_{j}^{r e s}=f^{o b s}-f^{p r e}\left(M_{j}\right) .
$$

Equation (A3) describes the model increase $\Delta M_{j}$ by:

$$
\Delta M_{j}=\operatorname{cof}_{j} \cdot p(j)
$$

where $c o f_{j}$ is a constant conversion factor for the $j$-th iteration with the same unit as the model increase, $p$ is the probability value.

For the forward magnetic field, its shape is independent of the source magnetization vector. We obtain

$$
f^{r e s}=\operatorname{cof}_{j} \cdot f^{\text {pre }}\left(\overline{\Delta M_{j}}\right) .
$$

So the factor $c o f_{j}$ can be obtained based on Equation (A6).

\section{REFERENCES}

AHRENS TJ \& JOHNSON ML. 1995. Shock wave data for rocks. In: AHRENS TJ (Ed.). Rock Physics \& Phase relations: A handbook of Physical Constants. AGU Reference Shelf 3, Washington, DC. p. 35-44.

ARZAMASTSEVAA, GLAZNEVVN, RAEVSKY AB \& ARZAMASTSEVALV. 2000. Morphology and internal structure of the Kola Alkaline intrusions, NE Fennoscandian Shield: 3D density modelling and geological implications. J. Asian Earth Sci., 18: 213-228.

BOTT MHP \& TANTRIGODA DA. 1987. Interpretation of the gravity and magnetic anomalies over the Mull Tertiary intrusive complex, NW Scotland. J. Geological Society, London, 144: 17-28.

CHANDRASEKHAR DV, MISHRA DC, POORNACHANDRA RAO GVS \& MALLIKHARJUNARAO J. 2002. Gravity and magnetic signatures of volcanic plugs related to Deccan volcanism in Saurashtra, India and their physical and geochemical properties. Earth Plan. Sci. Lett., 201: 277292.

DINDI EW \& SWAIN CJ. 1988. Joint three-dimensional inversion of gravity and magnetic data from Jombo Hill alkaline complex, Kenya. J. Geological Society, London, 145: 493-504.

DRENTH BJ, ANDERSON RR, SCHULZ KJ, FEINBERG JM, CHANDLER VW \& CANNON WF. 2015. What lies beneath: geophysical mapping of a concealed Precambrian intrusive complex along the lowa-Minnesota border. Can. J. Earth Sci., 52: 279-293.

DUTRA AC \& MARANGONI YR. 2009. Gravity and magnetic 3-D inversion of Morro do Engenho complex, central Brazil. J.S. Am. Earth Sci., 28(2): 193-203.
DUTRA AC, MARANGONIYR \& JUNQUEIRA-BRODTC. 2012. Investigation of the Goiás Alkaline Province, central Brazil: Application of gravity and magnetic methods. J. S. Am. Earth Sci., 33(1): 43-55.

DUTRA AC, MARANGONI YR \& TRINDADE RIF. 2014. Aeromagnetic and physical-chemical properties of some complexes from Goiás Alkaline Province. Braz. J. Geol., 44(3): 361-373.

FEDI M \& PILKINGTON M. 2012. Understanding imaging methods for potential field data. Geophysics, 77(1), G13-G24.

GOMES CB, RUBERTIE \& MORBIDELLI L. 1990. Carbonatite complexes from Brazil: A review. J. S. Am. Earth Sci., 3(1): 51-63.

IULIANO T, MAURIELLO P \& PATELLA D. 2002. Looking inside Mount Vesuvius by potential fields integrated probability tomographies. J. Volcanol. Geoth. Res., 113(3-4): 363-378.

JUNQUEIRA-BROD TC, ROIG HL, GASPAR JC, BROD JA \& MENESES PR. 2002. A Província Alcalina de Goiás e a extensão de seu vulcanismo kamafugítico. Rev. Bras. Geoc., 32(4): 559-566.

JUNQUEIRA-BROD TC, GASPAR JC, BROD JA, JOST H, BARBOSA ESR \& KAFINO CV. 2005. Emplacement of kamafugite lavas from the Goiás Alkaline Province, Brazil: Constrains from whole-rock simulations. J.S. Am. Earth Sci., 18(3-4): 323-335.

LACERDA FILHO JV. 2000. Programa Levantamentos Geológicos Básicos do Brasil. Geologia e Recursos Minerais do Estado de Goiás e do Distrito Federal. Scale 1:500.000. 2 ed. In: LACERDA FILHO JV, REZENDE A \& SILVA A (Org.). Goiânia, Brazil: CPRM/METAGO/UnB.

LASA Prospection and Engineer S.A. 2004. Project: Aerogeophysical survey of Goiás State, first phase. Survey and data processing final rapport. Rio de Janeiro, SGM/MME/CPRM and SIC/SGM/ FUNMINERAL/Goiás State, Brazil, vol. 22 and maps.

MANTOVANI MSM, RUGENSKI A, DIOGO LA \& SHUKOWSKY W. 2005. Integrated geophysical investigation of a possible new alkaline occurrence in southeast Brazil. J.S. Am. Earth Sci., 20(3): 259-266.

MARANGONI YR \& MANTOVANI MSM. 2013. Geophysical signatures of the alkaline intrusions bordering the Paraná Basin. J.S. Am. Earth Sci., 41(3): 83-98.

MAURIELLO P \& PATELLA D. 1999. Principles of probability tomography for natural-source electromagnetic induction fields. Geophysics, 64(5): 1403-1417.

MAURIELLO P \& PATELLA D. 2001a. Localization of maximum-depth gravity anomaly sources by a distribution of equivalent point masses. Geophysics, 66(5): 1431-1437.

MAURIELLO P \& PATELLA D. 2001b. Gravity probability tomography: a new tool for buried mass distribution imaging. Geophys. Prospect., 49(1): 1-12. 
MAURIELLO P \& PATELLA D. 2008. Localization of magnetic sources underground by a probability tomography approach. Prog. Electromagn. Res. M, 3: 27-56.

OKABE M. 1979. Analytical expressions for gravity anomalies due to homogeneous polyhedral bodies and translations into magnetic anomalies. Geophysics, 44: 730-741.

PATELLAD. 1997a. Introduction to ground surface self-potential tomography. Geophys. Prospect., 45(4): 653-681.

PATELLA D. 1997b. Self-potential global tomography including topographic effects. Geophys. Prospect., 45(5): 843-863.

PROSPEC S.A. Geologia, Prospecções e Aerofotogrametria. 1974. Projeto Iporá (aerogamaespectrometria e aeromagnetometria), Ministério das Minas e Energia, Departamento Nacional da Produção Mineral DNPM, Comissão Nacional de Energia Nuclear - CNEN, Companhia de Pesquisa de Recursos Minerais-CPRM, Convênio DNPM/CNEN/CPRM, Final Report, Rio de Janeiro, Brazil.
RICCOMINI C, VELÁZQUEZVF \& GOMES CB. 2005. Tectonic controls of the Mesozoic and Cenozoic alkaline magmatism in central-southeastern Brazilian Platform. In: COMIN-CHIARAMONTIP \& GOMES CB (Eds.). Mesozoic to Cenozoic alkaline magmatism in the Brazilian Platform. São Paulo, FAPESP, 31-55.

ROEST WE, VERHOEF J \& PILKINGTON M. 1992. Magnetic interpretation using 3-D analytical signal. Geophysics, 57(1): 116-125.

ULBRICH HHGJ \& GOMES CB. 1981. Alkaline rocks from continental Brazil: A review. Earth Sci. Rev., 17(1-2): 135-154.

ZHANG HL, MARANGONI YR \& RAVAT DD. 2014a. 3D rapid probability inversion for magnetization. Unpublished rapport to Research Foundation of São Paulo State, Brazil, 12 pp.

ZHANG HL, RAVAT D, MARANGONI YR \& HU XY. 2014b. NAV-Edge: Edge detection of potential field sources using normalized anisotropy variance. Geophysics, 79(3): J43-J53.

\section{NOTES ABOUT THE AUTHORS}

Yára Regina Marangoni received Ph.D. in Geophysics from Universidade de São Paulo (Brazil) in 1994. Teaching and conducting research at Universidade de São Paulo since 1988 on topics related to research for mineral exploration with gravity and magnetic fields and also regional tectonic features using gravity field. Research interest is gravity interpretation of regional tectonic features.

Henglei Zhang received B.Sc. in Applied Geophysics from China University of Geosciences (Wuhan) in 2002 and Ph.D. in Geophysics in 2011. Teaches and conducts research at China University of Geosciences on topics of exploration of mining and oil-gas with gravity and magnetic fields. In 2012 made a short visit to University of Kentucky working with Prof. Ravat. In 2013-2014 held a post-doctoral position at Universidade de São Paulo working with Prof. Marangoni. Research interests are processing, inversion methods and interpretation of potential field data. Also interested in the denoising methods of geophysical data.

Herbert Jorge Ferreira is pursuing a bachelor degree in Physics at Universidade de São Paulo, and works in the Gravity Lab of Instituto de Astronomia, Geofísica e Ciências Atmosféricas (IAG-USP) as a technician. 